\title{
Steyn, J G 1995 - Septuagint quotations in the context of the Petrine and Pauline Speeches of the Acta Apostolorum
}

Kampen: Kok Pharos. 290 pages. Price: unknown

\section{Reviewer: Prof S J Joubert}

With this excellent publication, which was originally presented as a doctoral thesis at the University of Pretoria under the guidance of Professor Cilliers Breytenbach from the Humbold Universität, Berlin, as promoter, Gert Steyn establishes himself as one of the leading young New Testament scholars in South Africa today.

In this very detailed and highly technical study, the use of LXX material as manifested in the explicit quotations in the Petrine and Pauline speeches in the book of Acts, is investigated. The aim of Steyn is to determine how Luke quoted from his Scriptures, and why certain changes were made to the texts quoted. In other words: he attempts to come to grips with Luke's use of the Greek versions of his Jewish Scriptures in terms of his own set of theological assumptions and the possible 'Textvorlage' which he made use of.

In chapter 1 an overview of developments in research on quotations in Acts, as well as research on introductory formulae, the origin and 'Textvorlagen' of the quotations, the classification and modes of quotations, and the function(s) of the various quotations is presented. This is followed by an identification of the explicit quotations from the LXX in Acts, and a brief discussion of the problematic nature of the text of the LXX (chapter 2).

In chapters 3-5 direct quotations in the speeches of Peter (Ac 1:16-22; 2:14-41; 3:11-26) are dealt with. Chapters 6-8, in turn, deal with Paul's speech in Antioch (Ac 13:16-41/48), his speech before the Sanhedrin in Jerusalem (Ac 22:30-23:9), and his speech to the Jewish leaders in Rome (28:16-28). Steyn meticulously investigates these speeches in terms of:

* The so-called text-historical problem. The explicit quotations are analysed to determine whether changes to the LXX texts quoted could have been the result of another 'Vorlage' that Luke had at his disposal (which differs from the present reconstructed Göttingen edition of the LXX), or whether Luke made these changes himself when he related passages from Scripture to his own context (or whether it represents a mixture of both). In this regard Steyn concludes that in spite of the fact that many of these quotations in the 'Acta Apostolorum' were already used before Luke's time, he used a 'Textvorlage' which closely resembles that of the reconstructed Old Greek Version and other LXX documents (p 232). There is not sufficient evidence that Luke had any knowledge of, or made use of a testimony book or existing written traditions.

* Luke's use of LXX quotations. According to Steyn, Luke used the quotations from the Scriptures on an informative level to indicate that certain past events had been fulfilled in the death and resurrection of Jesus. At the same time these quotations are used to address the present and future situation of his audience.

* Lukan theology. Steyn points out that Luke reinterprets the quoted material from his Scriptures in a Then-centric, rather than a christological manner, since God always remains the Subject (in terms of the 
resurrection of Jesus; the fulfilment of his promises in Scripture; the salvation history of Israel, the election motif; etc.). This and other aspects of Lukan theology, such as the pneumatological empowerment of the prophets and apostles, and the keryma about Jesus, are placed within a broader salvation historical approach.

In this first monograph on explicit quotations in the book of Acts, Steyn presents a reasoned and provocative answer to the nature of 'Textvorlage' which Luke (probably) used for his explicit quotations. He also gives valuable insights into the manner in which Luke reinterpreted his material to give expression to and support for his own theological views. However, in spite of the thorough text-critical work and careful exegesis of the speeches in question, the possible historical framework within which this reinterpretation and application of the quotations from Luke's Scriptures took place is never addressed. Within the parameters of a study of this nature, the (re)construction of a possible socio-historical situation which influenced Luke's understanding and use of these quotations, would have further enhanced the already high quality of this study.

It is also a bit disappointing that Steyn does not make any explicit use of, or reference to, recent theories on intertextuality. This study falls within this field of research. Steyn should have entered into a debate, at least on the theoretical level, with prominent theories and/or works in this regard.

Despite these criticisms, this study should be recommended to all serious scholars of the New Testament. It brings important new insights to bear on the origin of Luke's 'Textvorlage' and his use thereof. Scholars engaged in the study of Luke's works need to take seriously the insights and conclusions which Steyn puts forward in this scholarly work. 